\section{RSP}

http://www.rsp.fsp.usp.br/
Revista de Saúde Pública

\title{
Intimate partner violence and incidence of common mental disorder
}

\author{
Marcela Franklin Salvador de Mendonça', Ana Bernarda Ludermir"l \\ Programa de Pós-Graduação Integrado em Saúde Coletiva. Universidade Federal de Pernambuco. Recife, PE, Brasil \\ " Departamento de Medicina Social. Centro de Ciências da Saúde. Universidade Federal de Pernambuco. Recife, \\ PE, Brasil
}

\section{ABSTRACT}

OBJECTIVE: To investigate the association of intimate partner violence against women reported in the last 12 months and seven years with the incidence of common mental disorders.

METHODS: A prospective cohort study with 390 women from 18 to 49 years, registered in the Family Health Program of the city of Recife, State of Pernambuco; from July 2013 to December 2014. The Self Reporting Questionnaire-20 (SRQ-20) assessed mental health. Intimate partner violence consists of concrete acts of psychological, physical or sexual violence that the partner inflicts on the woman. Poisson regression was used to estimate crude and adjusted relative risks (RR) of the association between common mental disorders and intimate partner violence.

RESULTS: The incidence of common mental disorders was $44.6 \%$ among women who reported intimate partner violence in the last 12 months and $43.4 \%$ among those who reported in the past seven years. Mental disorders remained associated with psychological violence $(\mathrm{RR}=3.0$; 95\% CI 1.9-4.7 and $\mathrm{RR}=1.8 ; 95 \% \mathrm{CI} 1.0-3.7$ in the last 12 months, and seven years, respectively), even in the absence of physical or sexual violence. When psychological violence were related to physical or sexual violence, the risk of common mental disorders was even higher, both in the last 12 months $(\mathrm{RR}=3.1 ; 95 \% \mathrm{CI} 2.1-4.7)$ and in the last seven years $(\mathrm{RR}=2.5$; 95\% CI $1.7-3.8)$.

CONCLUSIONS: Intimate partner violence is associated with the incidence of common mental disorders in women. The treatment of the consequences of IPV and support for women in seeking protection for themselves for public services is essential.

Marcela Franklin Salvador de Mendonça

Rua Jaildo Figueira Priston, 175 Rio Doce

53080-530 Olinda, PE, Brasil

E-mail: marcelafs.mendonca@gmail.com

DESCRIPTORS: Battered Women. Mental Disorders, epidemiology. Intimate Partner Violence. Spouse Abuse.

\section{Received: 14 Jan 2016}

Approved: 8 Aug 2016

How to cite: Mendonça MFS, Ludermir AB. Intimate partner violence and incidence of common mental disorder. Rev Saude Publica. 2017;51:32.

Copyright: This is an open-access article distributed under the terms of the Creative Commons Attribution License, which permits unrestricted use, distribution, and reproduction in any medium, provided that the original author and source are credited. 


\section{INTRODUCTION}

Intimate partner violence (IPV) causes physical, sexual, or psychological harm, including physical assault, sexual coercion, psychological abuse, and controlling behaviors ${ }^{\mathrm{a}}$. This occurs with more moderate situations in which diverse conflicts or episodes of frustration and anger occasionally erupt into aggression, and a more serious and chronic, progressive pattern ${ }^{17}$.

Acts of violence against women are not isolated events; this pattern of behavior violates the rights of women and girls, limits their participation in society and impairs their health

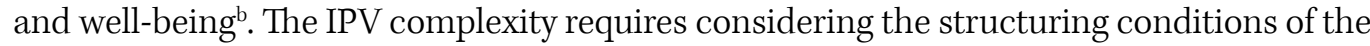
Brazilian social fabric, validating the focus on the cultural context of the patriarchal system, which generates power asymmetry in human interactions, and intensifying conditions to worsening human rights violations ${ }^{4}$.

Dantas-Berger and Giffin ${ }^{3}$ consider that a social order of patriarchal tradition has long "consented" to a certain pattern of violence against women, assigning man the "active" role in the social and sexual relationships, while restricting the woman to passivity and reproduction. The male power game comes from these beliefs that men have rights and privileges more than women ${ }^{4}$.

IPV originates social and economic costs, harming the whole society ${ }^{6,15}$. Women may suffer isolation, inability to work, loss of wages and lack of participation in regular activities, and limit their ability to care for themselves and their children ${ }^{\mathrm{a}}$.

The World Health Organization states that IPV is the most common type of violence against women, affecting $30 \%$ of women. It is a serious public health problem since it can lead to immediate injuries, infections and mental disorder ${ }^{5,13, b}$. The health sector has been slow to engage with violence against women.

Worldwide, mental health problems, emotional distress and suicidal behavior are common among women who have suffered IPV ${ }^{7, c}$. Common mental disorders (CMD) symptoms are insomnia, fatigue, irritability, forgetfulness, difficulty concentrating and somatic complaints, allied to depression and anxiety. CMDs cause a high social and economic cost due to lost days of work, as well as increasing health services demand ${ }^{8}$.

Using the Self Reporting Questionnaire-20 (SRQ-20) ${ }^{10}$, intimate partner violence, experienced by about $50 \%$ of Brazilian women, was associated with the CMD under analysis. The authors found a higher CMD among women who reported violence than among those who did not report violence (49\% versus $19.6 \%$, respectively). In addition, CMD increases with the severity of violence, with $30.6 \%$ for women who were victims of physical violence alone and $62.9 \%$ for those who suffered all forms of violence.

Women who have suffered IPV in the past may be more likely to have current psychological disorders than women who have never experienced IPV. The IPV effects on mental health can be immediate and acute, but also have long-term consequences or even become chronic ${ }^{16}$.

Estimating CMD in the population helps to understand its distribution in different groups in relation to its different characteristics, as well as the risk factors associated with its occurrence. The diagnosis provides relevant information to guide the policies of intervention in mental health, reducing or preventing worsening.

This study aimed to investigate the association of intimate partner violence reported against women in the last 12 months and the last seven years with the incidence of common mental disorders in women.

\section{METHODS}

This is a prospective cohort study, part of a larger study we started in 2005, at the Distrito Sanitário II, in Recife, State of Pernambuco, and two stages are already completed. 
The first stage occurred from July 2005 to October 2006, when we contacted pregnant women during the prenatal visit. Of the 1,133 women eligible for the survey, we interviewed 1,120 (98.9\%). The second stage occurred between three and six months postpartum. In the second stage, 1,057 women were interviewed, representing $94.3 \%$ of those who answered the first questionnaire.

This work is the third stage of the study. We invited all the women from the second stage to participate in this new phase, and they answered the same questions about violence that we did in the other stages, with reference to the last seven years and the last 12 months.

We used a structured questionnaire, in face-to-face interviews from July 2013 to December 2014 to data collection. The interviewers had higher education and experience in dealing with "violence against women". There were weekly discussions with the interviewers in relation to the difficulties they found during the interviews. Most interviews occurred at the women's home. The questions related to IPV were based on the questionnaire of the Multi-Country Study on Women's Health and Domestic Violence, of the World Health Organization, validated in Brazil ${ }^{18}$.

The questions characterized physical assaults or the use of objects or weapons to cause injury as physical violence; as psychological violence, threatening behavior, humiliations and insults; and as sexual violence, sexual relations through physical force or threats and imposition of acts considered humiliating. Previous publication has details ${ }^{10}$. If the woman answered "yes" to at least one of the questions to each type of violence, we considered as a positive case.

The partner or ex-partner with whom the women lives or lived was her intimate partner regardless of formal union, including current boyfriends, as long as they had sexual relations.

The SRQ-20 instrument, developed by the World Health Organization, assessed mental health; it detects psychiatric problems in primary healthcare for developing countries ${ }^{6}$, with twenty yes-no questions, four physical symptoms and sixteen on psycho emotional disorders. The SRQ-20 was validated in Pernambuco with $62 \%$ sensitivity and $80 \%$ specificity 9 . In the data analysis, we assigned one point for each affirmative response and zero for each negative response. The SRQ-20 cut-off score was $7 / 8^{6}$ and the groups were non-suspected CMD (score $\leq 7$ ) and suspected CMD (score $\geq 8$ ).

The questions related to their demographic and socioeconomic characteristics: age (24-27; $\geq 28$ ); race/ skin color (white; non-white); living with a partner (yes; no); years of education ( $0-4 ; \geq 5$ ); productive insertion (unemployed, others); monthly income (none; $<1$ minimum wage ${ }^{\mathrm{d}} ; \geq 1$ minimum wage). The data from the third Interview were typed in the EpiInfo program version 5.3.2, with double data entry and by different typists. Subsequently, the Validate software checked the typing errors and we cleaned and verified data consistency.

The Stata program version 10.1 for Windows performed statistical analysis. To test differences between proportions, we used the Chi-square test and considered those with $\mathrm{p}<0.05$ statistically significant. We used the Poisson regression to estimate the risk ratio (RR) and $95 \% \mathrm{CI}$ of the association between CMD, socioeconomic and demographic characteristics of women, and types of IPV in the last 12 months and the last seven years. Potential confounding factors were chosen based on the analysis of the socioeconomic and demographic characteristics.

The Committee of Ethics and Research with Human Beings of the Universidade Federal de Pernambuco approved the study (Opinion 194.672), in accordance with Resolution 196/96, which regulates research with human beings. All participants signed a free and informed consent form, read at the beginning of the interview, when women received information about the location and coordination of the research, their voluntary and confidential nature, and the delicate and personal nature of some questions. 


\section{RESULTS}

We interviewed $60.9 \%$ (644) of the postpartum women who answered the second stage of the cohort. Six women had died. We lack to find 390 women due to change of address and 17 refused to remain in the survey. However, these 390 postpartum women did not show a statistically significant difference in relation to IPV and demographic and socioeconomic variables.

We excluded 254 women out of 644 in the current database who had CMD during pregnancy, resulting in a sample of 390.

In agreement with the socioeconomic and demographic characteristics, most women were over 28 years of age, non-white, living with a partner and having five or more years of education. Most women were also unemployed and received less than 1 minimum wage. The incidence of CMD in the last seven years was higher in women with monthly income less than 1 minimum wage (Table 1).

In the 12 months prior to this study, $20.8 \%$ of women were victims of some type of violence. In relation to the last seven years, the victims of some type of violence totaled $26.2 \%$. Among women who reported IPV, the most frequent violence was psychological violence. Currently, $21.3 \%$ of all women were affected by CMD (Table 2). The incidence of common mental disorders was $44.6 \%$ among women victims of violence in the last 12 months and $43.4 \%$ in those who reported violence in the last seven years (Table 3 ).

The risk ratio (RR) was higher in physical and sexual violence with or without psychological. The incidence of CMD showed a strong association with violence in the last 12 months $(\mathrm{RR}=3.1 ; 95 \% \mathrm{CI} 2.1-4.7)$ and in the last seven years $(\mathrm{RR}=2.5$; 95\% CI $1.7-3.8)$, maintained even after adjusting RR for possible confounding factors (Table 3 ).

Table 1. Socioeconomic and demographic characteristics of women and their association with common mental disorders, risk ratio (RR), confidence intervals $(95 \% \mathrm{Cl})$ and $\mathrm{p}$ values.

\begin{tabular}{|c|c|c|c|c|c|c|}
\hline \multirow[t]{2}{*}{ Variable } & \multirow[t]{2}{*}{$\mathbf{n}$} & \multirow[t]{2}{*}{$\%$} & \multicolumn{2}{|c|}{$\begin{array}{c}\text { Common mental } \\
\text { disorder }\end{array}$} & \multirow[t]{2}{*}{$\operatorname{RR}(95 \% \mathrm{Cl})$} & \multirow[t]{2}{*}{$\mathbf{p}$} \\
\hline & & & $\mathbf{n}$ & $\%$ & & \\
\hline \multicolumn{7}{|l|}{ Age } \\
\hline $24-27$ & 56 & 14.36 & 11 & 19.6 & $0.9(0.5-1.6)$ & 0.749 \\
\hline$\geq 28$ & 334 & 85.6 & 72 & 21.6 & 1.0 & \\
\hline \multicolumn{7}{|l|}{ Race/Skin color ${ }^{\mathrm{a}}$} \\
\hline White & 70 & 18.0 & 14 & 20.0 & 1.0 & \\
\hline Non-white & 318 & 81.9 & 68 & 21.4 & $1.1(0.6-1.8)$ & 0.799 \\
\hline \multicolumn{7}{|l|}{ Living with a partner } \\
\hline Yes & 311 & 79.7 & 64 & 20.6 & $0.8(0.5-1.3)$ & 0.496 \\
\hline No & 79 & 20.3 & 19 & 24.0 & 1.0 & \\
\hline \multicolumn{7}{|l|}{ Years of education ${ }^{b}$} \\
\hline $0-4$ & 55 & 14.2 & 15 & 27.8 & 1.0 & \\
\hline$\geq 5$ & 332 & 85.8 & 67 & 20.2 & $0.7(0.4-1.2)$ & 0.221 \\
\hline \multicolumn{7}{|l|}{ Productive insertion } \\
\hline Unemployed & 311 & 79.7 & 60 & 19.3 & 1.0 & \\
\hline Other & 79 & 20.3 & 23 & 29.1 & $1.5(0.9-2.3)$ & 0.051 \\
\hline \multicolumn{7}{|l|}{ Monthly income } \\
\hline None & 35 & 9.0 & 5 & 14.3 & $0.9(0.4-2.3)$ & 0.853 \\
\hline Less than $\mathrm{R} \$ 678.00$ & 220 & 56.4 & 57 & 25.9 & $1.7(1.1-2.6)$ & 0.027 \\
\hline Equal or more than $\mathrm{R} \$ 678.00$ & 135 & 34.6 & 21 & 15.6 & 1.0 & \\
\hline
\end{tabular}

Missing data from 2 participants.

${ }^{\mathrm{b}}$ Missing data from 3 participants. 
Table 2. Frequency of intimate partner violence in the last 12 months and last seven years and common mental disorders.

\begin{tabular}{lcc}
\hline Variable & $\mathrm{n}^{*}$ & $\%$ \\
\hline IPV in the last 12 months & 309 & 79.2 \\
No violence & 37 & 9.5 \\
Only psychological & 44 & 11.3 \\
Physical and sexual with or without psychological & & 73.8 \\
IPV in the last seven years & 288 & 10.0 \\
No violence & 39 & 16.2 \\
Only psychological & 63 & \\
Physical and sexual with or without psychological & & 43.39 \\
Common mental disorders & & 56.61 \\
During the pregnancy & 486 & 21.3 \\
$\quad$ Yes & 634 & 78.7 \\
$\quad$ No & & \\
Currently & 83 & 307 \\
$\quad$ Yes & & \\
No &
\end{tabular}

IPV: intimate partner violence

* $\mathrm{n}$ during pregnancy $=1,120 ; \mathrm{n}$ in the last 12 months and last seven years $=390$.

Table 3. Incidence of common mental disorders in women victims of IPV in the last 12 months and the last seven years.

\begin{tabular}{|c|c|c|c|c|c|c|}
\hline Variable & $\mathbf{n}$ & $\%$ & Crude RR & $95 \% \mathrm{Cl}$ & Adjusted RR & $95 \% \mathrm{CI}^{*}$ \\
\hline \multicolumn{7}{|l|}{ IPV in the last 12 months } \\
\hline No violence & 46 & 55.4 & 1 & & 1 & \\
\hline Only psychological & 16 & 19.3 & 2.9 & $1.8-4.6$ & 3.0 & $1.9-4.7$ \\
\hline Physical and sexual with or without psychological & 21 & 25.3 & 3.2 & $2.1-4.8$ & 3.1 & $2.1-4.7$ \\
\hline \multicolumn{7}{|l|}{ IPV in the last seven years } \\
\hline No violence & 47 & 56.6 & 1 & & 1 & \\
\hline Only psychological & 12 & 14.5 & 1.9 & $1.1-3.2$ & 1.8 & $1.0-3.0$ \\
\hline Physical and sexual with or without psychological & 24 & 28.9 & 2.3 & $1.5-3.5$ & 2.5 & $1.7-3.8$ \\
\hline
\end{tabular}

IPV: intimate partner violence

* Adjusted by the "productive insertion" and "monthly income" variables.

\section{DISCUSSION}

This study estimated the incidence of common mental disorder in women victims of IPV, in which psychological violence was associated with $\mathrm{CMD}$ even when violence occurred without physical or sexual violence and after adjusting for other variables. The greatest association occurred in situations of physical and sexual violence with or without psychological violence in the last 12 months and in the last seven years, corroborating the findings of Ludermir et al. ${ }^{10}$, regarding the fact that $\mathrm{CMD}$ increases with the severity of violence. The small number of women victims of physical or sexual violence, similar to other studies ${ }^{10,20}$, made it impossible the analysis of these variables in isolation. To our knowledge, this is the first Brazilian cohort study estimating the incidence of CMD in women victims of IPV seven years after pregnancy.

According to our study, psychological violence was more common than physical and sexual violence and in women with low education and living with lower income, corroborating with other studies ${ }^{6,10,11,15}$. In fact, the frequency of IPV we found may reflect the characteristics of the territory of the study. Frequencies of violence also depend on the socioeconomic conditions of the population and on the sociocultural contexts in which the gender hierarchy is more or less legitimized, which contributes to the increase or decrease of violence reports ${ }^{20}$. 
Exposure to violence is a common feature of women living in developing countries and is significantly associated with mental health problems ${ }^{12,14}$. This may happen because developing countries are conservative and patriarchal societies that reinforce gender inequality ${ }^{2}$. Women who are victims of IPV are more likely to have CMD symptoms ${ }^{2}$. In addition, a systematic review reported a moderate or strong association between IPV and depression, suggesting that women victims of IPV are about three times more likely to develop depression ${ }^{19}$.

Studies report that the more severe the aggression, the greater the impact on women's mental health ${ }^{12,15}$. These studies are similar to our results, as we verified that the highest incidence of CMD occurred in women who reported more than one type of violence. This association may be a consequence of a greater frequency of violence against women, as well as of the more serious nature of violence, more common in situations with combined forms of violence ${ }^{1}$.

One of the limitations of this study is the information bias, regarding the underreporting of violence. Because it is a sensitive issue, stigma and shame can induce women to omit violence, leading to underreporting of the case ${ }^{10}$. In addition, women's difficulties and blockades to face the trauma and to remember this painful experience may interfere with their willingness to speak ${ }^{20}$. Thus, the results may be underestimated, leading to an underestimation of the strength of the association between violence and mental disorders.

The role of health professionals in identifying violence against women is still a matter of debate $^{20}$. There is evidence that IPV is associated with the high frequency of demand for primary healthcare services ${ }^{19}$. Health professionals should be aware of women suffering from CMD as this may indicate that they are victims of IPV, as these two issues are strongly associated with the results in this study. In addition, IPV is an aggravation of compulsory notification of public health in public and private health services throughout the national territory, contemplated by Law 10.778/2003, which establishes compulsory notification of violence against womene.

Sometimes physical violence occurs with psychological violence, so health professionals who are treating victims of intimate partner physical violence should be sensitive to symptoms of potential mental health problems and refer them to appropriate mental health services ${ }^{12}$.

This study reinforces that IPV, often reported by women in Brazil, is associated with CMD. Public policies and strategies aimed at reducing gender-based violence can help prevent and reduce CMD symptoms among women who are victims of violence. It is also essential to address the IPV consequences and to support women in seeking protection in public services.

\section{REFERENCES}

1. Beydoun HA, Beydoun MA, Kaufman JS, Lo B, Zonderman AB. Intimate partner violence against adult women and its association with major depressive disorder, depressive symptoms and postpartum depression: a systematic review and meta-analysis. Soc Sci Med. 2012;75(6):959-75. https://doi.org/10.1016/j.socscimed.2012.04.025.

2. Ceballo R, Ramirez C, Castillo M, Caballero GA, Lozoff B. Domestic violence and women's mental health in Chile. Psychol Women Q. 2004;28(4):298-308. https://doi.org/10.1111/j.1471-6402.2004.00147.x.

3. Dantas-Berger SM, Giffin K. A violência nas relações de conjugalidade: invisibilidade e banalização da violência sexual? Cad Saude Publica. 2005;21(2):417-25. https://doi.org/10.1590/S0102-311X2005000200008.

e Brasil. Lei no 10.778 , de 24 de novembro de 2003. Estabelece a notificação compulsória, no território nacional, do caso de violência contra a mulher que for atendida em serviços de saúde públicos ou privados. Brasília (DF); 2003 [cited 2014 Nov 3]. Available from: http:// www.planalto.gov.br/ccivil_03/ leis/2003/10.778.htm
4. Fonseca DH, Ribeiro CG, Leal NSB. Violência doméstica contra a mulher: realidades e representações sociais. Psicol Soc. 2012;24(2):307-14. https://doi.org/10.1590/S0102-71822012000200008.

5. Garcia-Moreno C, Jansen HAFM, Ellsberg M, Heise L, Watts CH. Prevalence of intimate partner violence: findings from the WHO multi-country study on women's health and domestic violence. Lancet. 2006;368(9543):1260-9. https://doi.org/10.1016/S0140-6736(06)69523-8.

6. Harding TW, Arango MV, Baltazar J, Climent CE, Ibrahim HHA, Ladrido-Ignacio L, et al. Mental disorders in primary health care: a study of their frequency and diagnosis in four developing countries. Psychol Med. 1980;10(2):231-41. https://doi.org/10.1017/S0033291700043993. 
7. Kim J, Lee J. Prospective study on the reciprocal relationship between intimate partner violence and depression among women in Korea. Soc Sci Med. 2013;99:42-8. https://doi.org/10.1016/j.socscimed.2013.10.014.

8. Ludermir AB. Inserção produtiva, gênero e saúde mental. Cad Saude Publica. 2000;16(3):647-59. https://doi.org/10.1590/S0102-311X2000000300013.

9. Ludermir $A B$, Lewis $G$. Is there a gender difference on the association between informal work and common mental disorders? Soc Psychiatry Psychiatr Epidemiol. 2005;40(8):622-7. https://doi.org/10.1007/s00127-005-0938-6.

10. Ludermir AB, Schraiber LB, D'Oliveira AFPL, França-Junior I, Jansen HA. Violence against women by their intimate partner and common mental disorders. Soc Sci Med. 2008;66(4):1008-18. https://doi.org/10.1016/j.socscimed.2007.10.021.

11. Ludermir AB, Valongueiro $S$, Araújo TVB. Common mental disorders and intimate partner violence in pregnancy. Rev Saude Publica. 2014;48(1):29-35. https://doi.org/10.1590/S0034-8910.2014048004538.

12. Meekers D, Pallin P, Hutchinson P. Intimate partner violence and mental health in Bolivia. BMC Womens Health. 2013;13:28. https://doi.org/10.1186/1472-6874-13-28.

13. Moura LBA, Lefevre F, Moura V. Narrativas de violências praticadas por parceiros íntimos contra mulheres. Cienc Saude Coletiva. 2012;17(4):1025-35. https://doi.org/10.1590/S1413-81232012000400024.

14. Ribeiro WS, Andreoli SB, Ferri CP, Prince M, Mari JJ. Exposição à violência e problemas de saúde mental em países em desenvolvimento: uma revisão da literatura. Rev Bras Psiquiatr. 2009;31 Suppl 2:S49-57. https://doi.org/10.1590/S1516-44462009000600003.

15. Rosa AG, Boing AF, Büchele F, Oliveira WF, Coelho EBS. A violência conjugal contra a mulher a partir da ótica do homem autor da violência. Saude Soc. 2008;17(3):152-60. https://doi.org/10.1590/S0104-12902008000300015.

16. Ruiz-Pérez I, Plazaola-Castaño J. Intimate partner violence and mental health consequences in women attending family practice in Spain. Psychosom Med. 2005;67(5):791-7. https://doi.org/10.1097/01.psy.0000181269.11979.cd.

17. Schraiber LB, D'Oliveira AFPL, França-Junior I, Diniz S, Portella AP, Ludermir AB, et al. Prevalência da violência contra a mulher por parceiro íntimo em regiões do Brasil. Rev Saude Publica. 2007;41(5):797-807. https://doi.org/10.1590/S0034-89102007000500014.

18. Schraiber LB, Latorre MRDO, França-Junior I, Segri NJ, D'Oliveira AFPL. Validade do instrumento WHO VAW STUDY para estimar violência de gênero contra a mulher. Rev Saude Publica. 2010;44(4):658-66. https://doi.org/10.1590/S0034-89102010000400009.

19. Schraiber LB, Barros CRS, Castilho EA. Violência contra as mulheres por parceiros íntimos: usos de serviços de saúde. Rev Bras Epidemiol. 2010;13(2):237-45. https://doi.org/10.1590/S1415-790X2010000200006.

20. Silva EP, Ludermir AB, Araújo TVB, Valongueiro SA. Frequência e padrão da violência por parceiro íntimo antes, durante e depois da gravidez. Rev Saude Publica. 2011;45(6):1044-53. https://doi.org/10.1590/S0034-89102011005000074.

Funding: Conselho Nacional de Desenvolvimento Tecnológico (CNPq - Process 475240/2011-1).

Authors' Contribution: Study design and planning: MFSM, ABL. Data analysis and interpretation. MFSM, ABL. Writing of the unpublished study: MFSM. Critical review of the unpublished study:MFSM, ABL. Final approval:MFSM.

Conflict of Interest: The authors declare no conflict of interest. 